Kacsirek László - Neulinger Ágnes

\title{
Az idegen nyelvű képzések lehetőségei és feltételei A kis vidéki főiskolák szempontjainak figyelembevételével
}

\author{
László Kacsirek - Ágnes Neulinger \\ Opportunities and preconditions of foreign language-taught study programs With a special focus \\ on small Hungarian colleges
}

\begin{abstract}
In many countries of the world and also in Hungary many higher education institutions develop international - mainly English-taught - study programmes. Such programmes offer many benefits for the institutions and their management, their faculty, their students and their administrative staff. One is a stable and increasing income that improves the HEl's financial stability, the stability of the institution itself and the security of jobs. Many of the benefits origin from internationalisation. Standards and requirements are high on the international education market, the HIEs have to develop a premium education. This requires an adequate organisational framework, high-quality infrastructure and all participants must be trained. Meeting the challenge offers development opportunities and ensures high quality for all participants. Small countryside colleges in Hungary cannot increase the number of their students domestically, the only way out is international education.
\end{abstract}

Key words: English-taught programmes, premium education, internationalisation

\section{ÖSSZEFOGLALó}

Magyarországon és külföldön egyaránt egyre több felsőoktatási intézmény indít idegen főképp angol - nyelvű képzést. Ez előnyös az intézmény és menedzsmentje, oktatói, hallgatói és adminisztratív dolgozói számára. Stabil és növekvő bevételt eredményezhet, ami növeli a pénzügy stabilitását és növeli az intézmény, így a munkahely biztonságát is. Az anyagi előnyökön túl a legnagyobb előny a képzés nemzetközi jellegéből fakad. Az intézmény és polgárai nemzetköziesednek, s a szigorú feltételek kifejlesztése és biztosítása valamennyiük számára fejlődési lehetőséget és magasabb minőséget eredményez. A nemzetközi piacon a követelmények magasak, prémium terméket kell kifejleszteni. Ehhez meg kell teremteni a szervezeti kereteket, az infrastrukturális feltételeket és valamennyi résztvevő munkatársat képzésben kell részesíteni. A kis vidéki főiskolák hallgatói létszáma számos ok folytán a hazai piacon nem bővíthető, egyetlen kiút a nemzetközi hallgatók képzése.

Kulcsszavak: idegen nyelvű képzés, prémium oktatás, nemzetköziesedés

\section{BEVEZETÉS}

Sokszor esik szó arról, hogy egy felsőoktatási intézménynek idegen nyelvű képzést kellene indítania. A kérdés az, hogy miért? Hiszen látni fogjuk - az idegen nyelven való oktatásnak számos feltétele van, a létrehozása és a múködtetése konfliktusokkal teli, pénzt is kell rá áldozni, és az eredmények sem jönnek azonnal. 
Ennek ellenére a világ számos fejlett országában már évtizedekkel ezelőtt több felsőoktatási intézmény indított angol nyelvú illetve a brit intézmények esetében nemzetközi - képzést. Magyar példa is akad: a Semmelweis Orvostudományi Egyetem évtizedekkel ezelőtt indította, s ma nagy nemzetközi elismeréssel és nyereséggel folytatja orvosi képzését angolul. Magyarországon egyre több intézmény kínálatában jelenik meg valamilyen idegen nyelvű program.

A kérdés az, hogy miért? Tanulmányunkban áttekintést adunk arról, milyen elónyei származhatnak egy felsőoktatási intézménynek, ha idegen nyelven is folytat képzést, a képzés kialakításának és múködésének feltételeit és a jól múködő képzés eredményeit, hatásait. Tanulmányunkban nem elméleti megközelítésre törekszünk: a magyar felsőoktatás esetéből indulunk ki, a kis vidéki főiskolák szempontjait is érintve.

\section{AZ IDEGEN NYELVŰ KÉPZÉS ELŐNYEI A FELSŐOKTATÁSI INTÉZMÉNY SZÁMÁRA}

Idegen nyelvű képzés létrehozásának számos előnye lehet. Melyek ezek az előnyök? Érnek-e ezek annyit, hogy érdemes legyen időt és energiát beleölni, konfliktusokat felvállalni, pénzt rákölteni? Véleményünk szerint igen; egy idegen nyelvû képzés kifejlesztése és működtetése a felsőoktatási intézmény számára többrétű és szerteágazó előnyöket képes biztosítani. Az alábbi sorok ezeket az előnyöket tekintik át. (Az idegen nyelvű képzés elvben lehet bármilyen idegen nyelven folyó képzés, azonban a legelterjedtebb az angol nyelvú képzés. Ennek oka az angol nyelv globális elterjedésében és szerepében keresendő. Az idegen nyelven való képzés, illetve a képzés kifejlesztésében rejlő előnyök minden nyelv esetében megjelennek, ellenben az üzleti eredménye a nem angol nyelvú képzéseknek a szúkebb piac következtében lényegesen szerényebb.)

Kit értünk azonban felsőoktatási intézményen? Ennek a látszólag egyértelmű kérdésnek a tisztázása kulcsfontosságú az idegen nyelvű képzés szempontjából, mert az érdekek, az előnyök és a követelmények - bár több ponton összefonódnak - eltérhetnek. Véleményünk szerint a felsőoktatási intézmény a következő szereplők összessége: maga az intézmény, mint olyan, a menedzsment (felsővezetés kancellár, rektor, rektorhelyettesek), az oktatók, a hallgatók és az adminisztráció (nem oktató dolgozók). (Előnyök jelentkeznek a felsőoktatási intézmények környezetében is. Az idegen nyelvű képzés hatással lehet a képzés városára és megyéjére-régiójára, annak vezetésére, helyi politikára, a környék vállalataira és más munkáltatóira, illetve a város és megye-régió közösségére is. Ennek tárgyalása érdekes lenne, azonban terjedelmi okok folytán azt csak érintőlegesen áll módunkban megtenni.) Valamennyi szereplő esetében jelentkeznek anyagi és nem anyagi előnyök, a következő alpontokban ezeket fogjuk értelmezni az említett érintettek esetében.

\subsection{Az intézmény}

Az intézmény maga, mint intézmény számos előnyét élvezheti az idege nyelvú képzésének. $\mathrm{Az}$ intézmény anyagi előnyei (jól múködő idegen nyelvű képzés esetén) három pontban foglalhatók össze: stabil és növekvő bevétel, az intézmény fennmaradása (illetve részleges függetlenedése az állami forrásoktól) és a hosszú távú működés finanszírozása.

Bevétel. Egy jól működő, nemzetközi szinten versenyképes idegen nyelvű képzés képes stabil és jelentős jövedelmet képes biztosítani az intézmény számára. Ez részben a diplomát adó programok tandíjából, részben a részképzés keretében (jellemzően egy, esetenként két szemeszter hosszan) tanulók tandíjából származik.

Fennmaradás és függetlenedés. A csökkenő hazai hallgatói létszám, a legtöbb intézmény esetében lecsökkent állami támogatás és más tevékenységek gyenge jövedelem generáló képessége következtében több intézmény 
Kacsirek László - Neulinger Ágnes: Az idegen nyelvű képzések lehetőségei és feltételei ...

bevétele csökkenésnek indult. A csökkenő és egyre alacsonyabb jövedelem egyre kevésbé képes finanszírozni a tevékenységeket és az emberi és infrastrukturális kapacitások fenntartását. Egy idő után ez elérheti a kritikus szintet és az intézmény fennmaradását veszélyezteti. Egy versenyképes idegen nyelvú képzés egyenletes és stabil növekedést képes biztosítani, ami jelentős mértékben képes hozzájárulni az intézmény fennmaradásához. A labilis pénzügyi helyzetben lévő intézmények fokozott mértékben függenek az állami forrásoktól, így magától az államtól is. Egy államtól független (piaci) jövedelem ezt a függést képes csökkenteni.

A hosszú távú működés finanszírozása. Amennyiben az idegen nyelvű képzés stabillá válik, képes tartósan is hozzájárulni az intézmény múködéséhez. Az idegen nyelvú programok esetében a tervezés gyakran tudatosabb és hosszabb távra szól. A külföldi partnerek sokszor egy-két évvel elöre járnak a tervezésükkel, így az ehhez való igazodás a kiszámíthatóságot és hosszabb távú gondolkodást/ -múködést is támogatja.

A nem anyagi előnyök árnyaltabbak.

Nemzetköziesedés, részvétel hálózatokban. Az idegen nyelvű képzések lehetővé teszik, hogy külföldi intézményekkel közös programok, oktatási és nem oktatási együttmúködések kezdődjenek. Egy nemzetközi szinten népszerú intézmény a hallgatók sokaságát vonza a világ minden országából. A Corvinus Egyetem Gazdálkodástudományi karán az elmúlt félévben 42 ország hallgatói tanultak, ami azt jelenti, hogy igazi nemzetközi környezet alakulhatott ki, amely mind az itt tanuló diákok, mind a partner intézmények számára fontos. Ugyanígy a nemzetköziesedéshez járul hozzá, hogy oktatóink is számos országból érkeznek, így rendszeresen tanítanak a programjainkban többek között angol, amerikai, szingapúri, osztrák, olasz és lengyel kollégák. Emellett a nemzetközi hálózatokhoz való csatlakozást/kötődést is érdemes megemlíteni, amely az intézmény oktatási/kutatási profilja, célcsoportja és pozícionálása alapján sokféle lehet.

Hazai és nemzetközi presztízs. A hazai és nemzetközi presztízs részben az idegen nyelvú képzés prémium jellegéből adódik. Másrészt az idegen nyelvű képzések, együtt az intézmény oktatási gyakorlatával és színvonalával további lehetőségeket is teremt. A Corvinus Gazdálkodástudományi kara esetében mindez elitklubokban való tagságban is megnyilvánul, úgymint a CEMS (Community of European Management Schools a világ vezető üzleti iskoláinak és egyetemeinek hálózata, aminek minden országból csak egy, a legjobb intézmény lehet a tagja) vagy a PIM tagság (mindegyik a menedzsment oktatás zárt, nemzetközi hálózata). A presztízst a nemzetközi akkreditációk is mutatják, hiszen ezek az oktatás magas minőségét jelzik mind a hazai, mind a nemzetközi partnerek (és versenytársak) felé. Karunk jelenleg két nemzetközi program akkreditációval (EPAS a 'European Programme Accreditation System' rövidítése, az EFMD (Management Development Network) program akkreditációja) rendelkezik, de célunk hogy kari szinten is elnyerjük elöször az AACSB (Advancing Quality Management Education Worldwide) akkreditációját.

A szervezeti kultúra fejlödése. Az idegen nyelvú oktatás a szervezeti kultúra fejlődését is magával hozza. Ez azt jelenti, hogy külföldi hallgatók és oktatók jelenléte révén csökken a belterjesség a szervezeten belül, a nemzetközi sokszínűség elfogadása és megértése pedig a rugalmasságot és együttműködést erősíti az intézményben. Azaz a szervezet a nemzetközi kapcsolódás miatt egyre befogadóbbá válik, folyamataiban nyitottabb lesz és megközelítésében nem csak a szervezet belső világából és korlátaiból indul ki.

Alap a csereprogramok számára. Az idegen nyelvű képzés az alapja az Erasmus program múködtetésének: ezen belül a hallgatók és oktatók fogadásának, illetve a viszonosság elve alapján a külföldi programokban a magyar 
hallgatók, oktatók és adminisztratív dolgozók részvételének. A Corvinus Gazdálkodástudományi kara szempontjából az Erasmus kapcsolatok elsősorban a nemzetközi sokszínűség szempontjából fontosak, illetve ezeken keresztül (is) tudunk a hallgatóinknak külföldi részképzésekben való részvételt biztosítani. Továbbá az egyetem sok partnere esetében ez az együttmúködés első szintje. Összességében a Corvinuson a hangsúly az Erasmus partnerségek fókuszálásán és a legjobbak/legfontosabbak megtartásán van - és nem a kapcsolatok kiterjesztésén - hiszen számos partnerséggel rendelkezik az egyetem, ahol jellemzően több hallgatót fogad, mint amennyien kiutaznak.

\subsection{A menedzsment}

A menedzsmentnek akár, mint menedzsereknek, akár mint magánszemélyeknek többféle előnye származhat. Akárcsak az intézmény esetében, a menedzsment számára is jelentkeznek anyagi és nem anyagi előnyök.

Bevétel. Az idegen nyelvű programokból származó bevétellel nőnek az intézmény bevételei, amit az intézmény menedzsmentje használ fel, hiszen ebből is finanszírozza a rá bízott intézmény múködését. $A$ nagyobb intézményi bevétel nagyobb költségvetést jelenhet, amely a szervezet anyagi önállóságán túl a menedzsment lehetőségeinek a bővülésével is járhat.

Több forrás jut fejlesztésre és jutalmazásra. A magasabb bevétel szélesebb pénzügyi lehetőségeket nyújt, amely például az oktatással összefüggő fejlesztések finanszírozását is biztosíthatja. Ez lehet az emberi erőforrások fejlesztése (pl. oktatásmódszertan, nyelvtudás), de akár jelentheti az infrastruktúra fejlesztését is. Emellett a bevételekből lehetőség nyílhat a jól dolgozó és többlet teljesítményt nyújtó munkatársak jutalmazására, illetve a jobb munka anyagi ösztönzésére.
Nemzetközi kapcsolatok, utazás. Az intézmény vezetői szervező-vezetői munkájuk részeként külföldi partnerekkel tárgyalnak, gyakran külföldön. Ez nemzetközi környezetben való munkavégzéssel és külföldi utazással is jár, hiszen a nemzetközi kapcsolatokat - főleg egy szolgáltatás alapú iparágban - nem elegendő az íróasztal mellől irányítani. Ez részben elvárás a menedzsmenttól, részben nemzetközi munkakörnyezetet jelent, amely motiváló is lehet számukra.

Magasabb jövedelem. A menedzserek a többletmunkáért kiegészítő jövedelemhez juthatnak, egyes konkrét projektek konkrét projektmenedzseri díjai eredményezhetnek magasabb személyes jövedelmet.

Személyes menedzsment skillek fejlödnek. A külföldi oktatókkal és diákokkal végzett közös munka, az idegen nyelvű programok fejlesztése, a különböző projektek vezetése stb. a személyes vezetői készségek fejlesztéséhez is hozzájárul, illetve meg is követeli azt. Ez azt jelenti, hogy nő az egyéni tudásszint és ehhez kapcsolódóan a vezető munkapiaci értéke is.

Presztízs. Egy jól múködő nemzetközi képzési program sikere nagymértékben múlik a vezetők munkáján, így az növeli a vezetők személyes jó hírét, szakmai megítélését, presztízsét mind hazai, mind nemzetközi szinten.

Az intézményi és vezetői érdekek gyakran távol esnek az intézmény „tömegeitől”, az oktatóktól, hallgatóktól, adminisztratív dolgozóktól. A „fent” érdekei, az „ún.” intézményi érdekek és a vezetés elképzelései gyakran nem találnak megértésre az intézmény más polgárai körében. Ez utóbbiak távolinak érezhetik az intézményi és vezetői célokat, nem tudnak azonosulni velük, nem is igen értik, azokra miért van szükség és a tervek hogyan fogják majd befolyásolni az ő életüket. Márpedig sikeres idegen nyelvú képzés csak úgy hozható létre és múködtethető, ha minél szélesebb körben vesznek részt a folyamatban, másrészt az intézmény valamennyi polgára profitálhat 
belőle - különböző mértékben és részben a saját hozzáállásának függvényében. Nagy hangsúlyt fektetünk tehát arra, milyen előnyei származnak a felsőoktatási intézmény polgárainak, a "tömegeknek". Három csoportot vizsgálunk: oktatók, hallgatók és adminisztratív dolgozók. Mindhárom csoport esetében két jól elkülöníthető további csoport különíthető - és különítendő - el: aki közvetlenül részt vesz benne és aki nem. Előnyök mindkét csoport számára jelentkeznek, de eltérő módon és eltérő intenzitással.

\subsection{Oktatók}

Az oktatók számára az idegen nyelvű képzésben való részvétel kétségtelenül nagy kihívás, ugyanakkor számos előnyt is kínál. Említhetjük elsőnek a közvetlen anyagi előnyt: az idegen nyelven való oktatásnak többnyire magasabb az óradíja, illetve amennyiben az oktató a kötelező óraszámában „számolja el” a teljesítményt, magasabb szorzót alkalmazhat. Az előnyök között azonban nem a közvetlen anyagi elóny a legjelentősebb. Az idegen nyelvű képzésben való részvétel az oktató részéről magasabb teljesítményt, jobb minőséget, a megszokottól gyakran eltérő módszertant és még sok minden mást (lásd később) követel meg, amire fel kell készülnie. A felkészülés során az oktató személyes kompetenciái jelentős fejlődésen mennek át. Új módszertant tanul, bővül a látóköre, nyelvtudása minőségi fejlődésen megy keresztül, más kultúrákat ismer meg. Ezáltal az oktató nemzetközi szinten értékesíthető készségeket fejleszt ki, magasabb szintû oktatásra, magasabb minőségú szolgáltatásra válik képessé. Ez növeli a presztízsét, egyéni piaci értéke nő, s - végső soron - mindez anyagi előnyökre is váltható. Munkája során nemzetközi hallgatói csapattal dolgozik, ami sok érdekességet rejt magában, hiszen nemzetközi hallgatói csapattal érdekesebb és élvezetesebb dolgozni. Az oktató napi munkájának részévé válik a nemzetközi közegben való dolgozás, beleértve gyakoribb külföldi utazásokat is akár.

Milyen előnyöket élvezhet a képzésben részt nem vevő oktató? Az első, szinte „ölébe hulló" előny az idegen nyelvű képzés által generált nemzetköziesedés. Az intézmény nemzetközi kapcsolatai minőségben és mennyiségben fejlődnek, a kapcsolatok és nemzetközi partnerek, a külföldi tapasztalatszerzés - pl. Erasmus-ösztöndíj - más oktatók számára is elérhetők. A programban részt nem vevő oktató számára motivációt jelent, hogy bekerüljön az idegen nyelven oktató „elitbe”, s ez a fentebb leírt személyes fejlődést eredményezheti. Még ha nem is célja részt venni a programban, az idegen nyelvű képzésből átgyưrúzik a tudás és szakértelem, ami a saját oktatási minőségét növeli. További előnyök az intézményi hatásokból fakadó hatások, mint pl. jobb hangulatú intézményben dolgozhat, nő az intézmény stabilitása, ami biztosabbá teszi a munkahelyét és a megélhetését.

\subsection{Hallgatók}

Az idegen nyelvú képzésben tanuló hallgatók amennyiben a képzés valóban magas, a nemzetközi követelményeknek megfelelő szintű - nagyon sokat nyernek a képzésben való részvétellel. Ugyan az esetek döntő többségében - Magyarország esetében Magyarországon akkreditált képzési programban vesznek részt, azaz tartalmát tekintve a képzés ugyanaz, mint amiben magyar nyelven tanuló társaik részt vesznek, valójában attól sok mindenben különbözik - még tartalmát tekintve is. "Papíron” sok minden egyezhet, a tantárgyak lehetnek ugyanazok, a tartalom fö vonalaiban egyező, azonban a tanítás és tanulás a tantermekben történik. A hallgatók ugyanazokból a tankönyvekből tanulnak, mint a hasonló nemzetközi képzésekben világszerte mindenki más; ezek a tankönyvek - szemben a hazai piacon kapható és az oktatásban használt, tankönyvnek valójában sokszor nem nevezhető szakkönyvekkel - módszertani és tanulási szempontból kiforrott könyvek, esettanulmányokkal, feladatokkal, tanulási támogatással. A nemzetközileg "akkreditált" könyvek tartalma is átszivárog a tantárgyakba, erősítve azok nemzetközi szinthez való igazodását. Amennyiben a képzés menedzserei 
Kacsirek László - Neulinger Ágnes: Az idegen nyelvű képzések lehetőségei és feltételei ...

megfelelő szigorral vezetik a képzést, az oktatás módszertana készségközpontú, ami - szemben a tudástranszfer alapú oktatással használhatóbb és versenyképesebb „tudást” ad.

Óriási előnyt jelent más hallgatókkal szemben az otthon kínált nemzetköziesedés lehetősége (internationalisation at home). A hallgatóknak nem kell külföldre menniük, hogy nemzetközi tapasztalatai legyenek, más kultúrákat, szokásokat ismerjen meg. Hallgatótársai között vannak belgák, spanyolok, kínaiak, oroszok és sok más nemzet tagjai. Megtanulják, hogy mennyire különbözőek lehetünk, mi emberek, s hogy mégis nagyon jól lehet dolgozni a különbségek ellenére - ezt azonban meg kell tapasztalni és gyakorolni kell. Erre egy idegen nyelvű képzésben való részvétel lehetőséget biztosít.

A hallgató idegen nyelven tanul mindent, $s$ mivel ezt három évig teszi, nyelvtudása a "tantermi heti kétszeri" szintről természetessé, mindennapivá válik.

Milyen előnye származhat a képzésben részt nem vevő hallgatóknak? Az előnyök hasonlók az oktatók által élvezhető előnyökhöz, és főképp az intézmény nemzetköziesedéséből fakadnak. $\mathrm{Az}$ oktatók személyes kompetenciáinak fejlődése megjelenik az oktatás minőségében, aminek előnyeit minden hallgató élvezi. $A z$ intézményben tanuló nemzetközi hallgatók „rendelkezésre állnak”, lehet velük beszélgetni, programokon részt venni, el lehet menni velük bulizni. $\quad A z$ intézmény nemzetközi kapcsolatainak bővülésével bővül a nemzetközi ösztöndíjak és külföldi tanulási lehetőségek száma és köre, egyre több hallgató utazhat külföldre. Kialakulhat és nőhet az idegen nyelven bárki számára felvehető tárgyak száma, ami a nyelvi készségek fejlődését és más előnyöket is eredményezhet.

Ezekért az előnyökért azonban a hallgatóknak tenniük kell - bár elérhető közelségben vannak, értük kell nyúlni.

\subsection{Adminisztráció (nem oktató dolgozók)}

Sokan, sok intézményben úgy érzik - „mások” és maguk az adminisztratív dolgozók is - hogy az oktatásban közvetlenül részt nem vevő, adminisztratív vagy oktatást támogató munkát végző dolgozóknak semmilyen előnyük nem származik abból, hogy az intézmény idegen nyelven folytat képzést. Sőt, mivel a „szokásostól” eltérő ügyek, esetek és munkák jelennek meg a nemzetközi programok hatására (magyarul nem beszélő külföldiek jelennek meg a kollégiumban, vagy például a magyar adószabályoknak nem megfelelő, egy pakisztáni bevándorló által kiállított londoni taxiszámla) még „kényelmetlen” többletmunkát generál. Ez azonban nem így van; egy jól múködő idegen nyelvű képzés előnyös az ő számukra is. A képzéshez kapcsolódó munkát végző dolgozók - pl. tanulmányi adminisztráció - hasonló előnyöket élveznek a maguk speciális területén, mint az oktatók. Ilyenek a nyelvi készségek fejlődése, a rendszerezettebb, racionálisabb munkaszervezés, a szervezeti kultúra fejlődése, külföldi tapasztalatszerzési lehetőségek (pl. Erasmus személyzeti mobilitás!). S akár részt vesz a programban a dolgozó, akár nem, a program hatására az intézmény stabilitása és anyagi pozíciója erősödik, így a kolléga munkahelyének és a jövedelmének biztonsága nő.

Valamennyi érdekelt számára van még egy nagyon fontos elöny - vagy inkább kényszer? Ezt azonban gondolatmentünk végére tartogatjuk.

\section{AZ IDEGEN NYELVŰ KÉPZÉS KIFEJLESZTÉSÉNEK ÉS MŰKÖDTETÉSÉNEK FELTÉTELEI}

A fenti előnyök megszerzése érdekében az egyetem vagy főiskola meghozza a döntést: szeretne angol nyelvű képzést. A következő lépés így annak értelmezése, hogy mit kell tennie azért, hogy idegen nyelvű képzése legyen? 
Kacsirek László - Neulinger Ágnes: Az idegen nyelvű képzések lehetőségei és feltételei ...

Kiindulásunk a következő „axióma”: minden felsőfokú intézmény kezdetben alkalmatlan idegen nyelven folyó képzésre.

Miért?

- A külföldi hallgatóknak más igényeik vannak

- Mások a szokásaik, más a kultúrájuk

- Az oktatás módszertanában is eltérőek a követelmények

Összességében az intézménynek mindenben jobbat kell nyújtani, mert nemzetközi porondra lép ki, nemzetközi versenyre számíthat, így nemzetközi szinten kell képesnek lennie csinálni mindent - és ez nem csak nyelvi kérdés!

Ezzel az angol egyetemeknek és főiskolásoknak is szembesülniük kellett - pedig náluk az angol nyelv nem is okozott gondot (a legtöbbjük jól tud angolul (:)). Az Egyesült Királyságban is drasztikusan csökkent a hallgatói létszám, a kiút a külföldi hallgatók fogadása volt. Az első próbálkozások azonban sok kudarccal jártak Miért?

\section{Nézzük a feltételeket!}

A legfontosabb, hogy az idegen nyelvú képzésben - amely ideálisan bevétellel járó képzés - az intézménynek mindenben a legjavát kell nyújtania: oktatásban, infrastruktúrában, hallgatói szolgáltatásokban, mindenben. Éppen ezért a programnak kiemelt figyelemben kell részesülnie, az intézmény „prémium” termékének kell lennie, s mindenből a legjobbat kell kapnia. Az idegen nyelvű képzés az intézmény „prémium” terméke, ami jelentős bevételt képes generálni. A külföldi hallgató fizető ügyfél, $s$ nem "megtűrt" hallgatója az intézménynek. Ez azonban egyáltalán nem azt jelenti, hogy megveszi a diplomát, hanem azt, hogy az odáig vezető útját prémium szolgáltatásokkal segíti az intézmény, ami magában foglalja a prémium oktatást, prémium ügyfélszolgálatot, prémium tantermet, prémium lakhatást.

A feltételeket három kategóriába soroltuk:

1. Intézményi - szervezeti
2. Személyi

3. Infrastrukturális feltételek.

3.1. Intézményi - szervezeti feltételek $\mathrm{Az}$ angol nyelvű képzés létrehozásának szerepelnie kell az intézményi stratégiai célok között, és ott is kiemelt pozícióval kell bírnia. Döntsön róla a vezetés és a szenátus. Nem elég meghozni a döntéseket, majd hátradólve várni az eredményeket. Nagyon alaposan végig kell gondolni a várt előnyöket, hogy az idegen nyelvű képzésnek milyen helye, szerepe van az intézmény hosszú távú stratégiai céljai között, milyen elvárások vannak a programmal szemben. Végig kell gondolnia a feltételeket, azok teljesítésének módját és költségeit. Tervezni kell, számolni kell, hatástanulmányt kell készíteni. Mivel sok az érintett, így sok munkatárs munkáján, de inkább hozzáállásán múlhat a bevezetés sikere. Ezért széleskörú konzultációt szükséges folytatni valamennyi érintettel és meggyőzni őket a program várható intézményi és személyes előnyeiről. Komolyan kell gondolni, valóban akarni kell, nem csak formálisan. Sok képzés bukott el a valós vezető támogatás és a szervezeti konzultáció hiányában.

A vezetésnek tudatosan kell megteremteni a feltételeket és az így létrehozott dolgokat múködtetni kell. Tudatosan kell felkészülni, és a kollégák megnyerése vagy az elkötelezettek kiválasztását követően - kötelező elemekkel. A felkészülésben, a belső képzésekben kötelezően részt kell venni. Az egyes feltételeket, elemeket mérhetővé kell tenni és mérni is kell. Egy ténylegesen múködő ISO-rendszer nagyon sokat segíthet mindebben.

Éppen ezért, annak érdekében, hogy ezt képes legyen az intézmény elérni, az idegen nyelvű képzés minden elemét önálló szervezeti egységbe kell szervezi. Mit jelent ez?

$\mathrm{Az}$ oktatás menedzselésében, beleértve az oktatók kiválasztását a képzés vezetője dönt. Értelemszerűen saját érdeke, hogy egyeztessen a szakértő tanszékkel, de a döntést ő hozza meg. A jól működő nemzetközi képzési 
programok döntő többsége esetében is így múködik ez. Az önálló szervezeti egységbe kell szervezni a teljes hallgatói adminisztrációt, beleértve a tanulmányi adminisztrációt is.

Ha nem is teljes mértékben, de a képzéssel kapcsolatos marketingtevékenység egy részét is az önálló szervezeti egységre kell bízni, erre a célra biztosított forrásokkal, költségvetéssel. Időnként meg kell látogatni a partnereket, el kell menni hazai és nemzetközi vásárokra, költeni kell online marketingre. A szervezeti egység munkatársai ismerik a partnereket, az elvárásokat, a kultúrát - a képzés nemzetközi marketingje ugyanolyan mértékben különbözik a hazai piaci értékesítéstől, mint maga a képzés. Az intézmény marketingesei általában nem rendelkeznek a nemzetközi értékesítéshez szükséges speciális tudással.

S végezetül az önálló szervezeti egységnek rendelkeznie kell valamilyen szinten önálló gazdálkodási joggal. Ez nem azt jelenti, hogy pénzügyi szempontból független az intézmény egészétől, s azt sem, hogy profit centerként kell múködnie. Fontos azonban, hogy legyen költségvetési kerete, amivel gazdálkodni tud. Ennek hiányában, amennyiben minden egyes kiadást, oktatói óradíjat, reprezentatív költséget (pl. külföldi partner vacsorameghívását) az intézményi döntéshozatali-bürokratikus rendszeren kell átfuttatnia, képtelen lesz a színvonalas, gyors reagálású múködésre. Ez a részleges gazdasági önállóság természetszerǔen kötelezettségekkel jár, mint pl. bevételi és kiadási terv, és a program profitjával sem ő gazdálkodik, hiszen gazdasági szempontból - az idegen nyelvű képzés a felsőoktatási intézmény jövedelemszerző „vállalkozásainak” egyike.

$\mathrm{Az}$ idegen nyelvú képzés önálló szervezeti egységbe való szervezése sarkalatos pontja az a program működtetésének, aminek a jelentőségét és szükségességét sokan nem értik meg. Két érvet emelünk ki mellette:

1. Az intézmények döntő többsége úgy ahogy van, nem felel meg a nemzetközi követelményeknek a szolgáltatások minősége tekintetében. Ha megfelelne, akkor az azt jelentené, hogy minden egyes oktatója, minden egyes középvezetője, minden egyes oktatásszervezője, minden egyes hallgatói ügyet kezelő ügyintézője, minden egyes terme és projektora megfelel. Nem felel meg.

2. Az angol nyelvű képzésnek sajátosságai vannak: ezeket az intézmény polgárai nem ismerik - honnan is ismernék?. Az intézmény minden szolgáltatásával a hazai hallgatók igényeihez igazodik. Ez normális. A nemzetközi hallgatónak azonban mások az igényeik. Kell tehát egy erre szakosodott, szakértő szervezet, ami ezt a prémium terméket menedzseli.

Ennek érzékeltetésére vegyünk egy mezőgazdasági példát. Magyarországon sokféle, hazai termesztésű alma kapható. Ezek olyan almák, amelyek a hazai piacon eladhatók, és amelyek a hazai igényeket elégítik ki. Alma tekintetében a magyar piac közepesen igényes; eladható a kevésbé piros (vagy más karakteres színű), kicsit ütődött, nem annyira zamatos, belül is kicsit puha alma. A magyar vevő árérzékeny, $\mathrm{s}$ az alacsony ár gyakran fontosabb, mint a kiváló minőség. A tömegek inkább megveszik a kevésbé zamatos hazai jonatánt kétszáz forintért mint a ropogós, sötétvörös, ropogós olasz Modit kilencszázért. A termelők a hazai piacon ilyen almákat termelnek, mert a hazai piacnak ez megfelelő, nem követelte meg vagy nem fizeti meg a jobb minőséget - aminek az elóállítása is nehezebb és drágább.

Külföldön, a nemzetközi piacon azonban az ilyen alma nem eladható. A nemzetközi verseny nagy, kiélezett, nagyon sok termelő akarja eladni az almáit más országokban. A kínálat nagy, csak a kiváló minőségű, nagy, ropogós, zamatos, mosolygós alma adható el. Éppen ezért minden ország a prémium almáit viszi a nemzetközi piacra - Magyarország is - mert ami nem prémium, a nemzetközi piacon nem eladható. Ugyanez igaz a felsőoktatásra is. Az intézmények a hazai piacon olyan képzéseket 
fejlesztettek ki és adnak el, amelyek a hazai piacnak „elég volt". Most azonban a nemzetközi piacon akarják értékesíteni a képzésüket, tehát prémium almát kell termelniük. Ez azonban csak akkor megy, ha az kiemelt projektté válik. Hirtelen nem lehet minden almafát lecserélni, $s$ az új fák telepítését szakértő kertészcsapatra kell bízni!

\subsection{Személyi feltételek}

$S$ most nézzük a személyi feltételeket. $A z$ oktatás szolgáltatás, s mint olyan, a siker kulcsa az emberi erőforrásokban rejlik. Ez vonatkozik mind az oktatókra, mind a képzéshez kapcsolódó adminisztratív dolgozókra. A megfelelő nyelvtudás alapvető, de önmagában nem elégséges feltétel. Mit kell még tudni?

Mind tanárnak, mind ügyintézőnek ismernie kell és el kell fogadnia a külföldi hallgatók sajátjától eltérő szokásait és kultúráját. Nyitottnak és befogadónak kell lennie, $s$ tudnia kell megfelelően kezelnie az eltérő kultúrához kapcsolódó konfliktusokat is. Ez nem könnyú. Nézzünk erre egy példát. Egy hazai kis főiskola oktatói és adminisztratív dolgozói nemigen tudták helyesen kezelni eddigi két fekete afrikai hallgatójuk időnként mutatott viselkedését. A két hallgató - egy nő és egy férfi - ha problémájuk volt, igen nagy hanggal, gyakran ajtókat és asztalokat csapkodva próbáltak vélt igazuknak érvényt szerezni. A férfi hallgató ráadásul igen agresszív is volt, főképp nőkkel szemben, akik féltek is tőle. Ellenben egy magasabb rangú, férfi kollégával szemben igen tisztelettudóan viselkedtek mindketten. Mindkettő a kultúrájukból származik. Egy másik példa: nem ritka, hogy mexikói hallgatóknak az adott héten a harmadik nagymamájuk halt meg, ha épp meg kellett magyarázniuk, miért nem voltak órán vagy miért nem adták be időben a házidolgozatukat.

Fontos tehát a tudatos, formális és kötelező képzés. A képzés terjedjen ki a nyelvre, az interkulturális kommunikációra - de konkrétan bizonyos kultúrára vagy kultúrákra, ha egy bizonyos kultúrkörből sok hallgató várható. $A$ felkészítés során nagy hangsúlyt kell fektetni hallgatóközpontú oktatásra és ügyintézésre; a nemzetközi hallgató sok pénzt fizető ügyfél, elvárja, hogy ennek megfelelő szolgáltatásokban részesüljön, különféle ügyeit hatékonyan és gyorsan segítsenek neki intézni.

A felkészülés során azonban a legfontosabb az oktatás-módszertani képzés. És ami különösen fontos: Nemzetközi szinten a Magyarországon még mindig domináns „preaching” típusú, kiállok és hirdetem az igét, „a hallgató meg hallgasson, azért hallgató" jellegú oktatás és szemlélet nem eladható. Nemzetközi programokban az angolszász típusú, hallgató- $\mathrm{s}$ készségfejlesztés-centrikus oktatás az elvárt, az az etalon. Az oktatók többsége nem így oktatat, nem is így szocializálódott sem mint hallgató, sem mint oktató. Még ha igyekszik, törekszik is másképp átadni tárgyának ismereteit és készségeit, nehezen megy - nehéz önállóan hatékony módszertant kifejleszteni. Erre fel kell készíteni. Fel kell készíteni, hogyan vonja be a hallgatókat, hogy a hallgatók "csináláson" keresztül tanuljanak, meg kell mutatni, hogyan kell esettanulmányokkal dolgozni, nemzetközi példákat hozni, stb. stb. Ez kötelező elem.

\subsection{Infrastrukturális feltételek}

Nem elhanyagolhatók az infrastrukturális feltételek. Több intézménynél elszörnyedve tapasztaltuk, hogy kisszámú nemzetközi hallgatói csoportokat - maradék-elven - kis, sötét, lerobbant teremben helyeztek el, oktatásra-tanulásra alapvetően alkalmatlan körülmények közé. Ez nem megengedhető; az infrastrukturális feltételeknek is a legkiválóbbaknak kell lenniük. Prémium képzésnek nemcsak prémium oktatás, prémium szolgáltatás hanem prémium infrastruktúra is „jár". Az intézménynek a legjobb termeti, legjobb kollégiumi szobáit, stb. kell a nemzetközi program rendelkezésére állítania. A piac ezt igényli - ha ezt nem kapja meg, a barátja, testvére már nem hozzánk, hanem máshová megy tanulni. Ha az infrastruktúra nem képes kielégíteni ezeket az igényeket, akkor bizony fejleszteni kell. 
Az általános rendezőelv mellett, hogy az intézmény a legjobbat biztosítsa a prémium termékének, itt is vannak kötelező elemek. A termeknek igazodniuk kell az oktatás módszertanához. A példa kedvéért a szemináriumi termek ne kisiskolásan legyenek berendezve, sorba rendezett padokkal, székekkel, ahol a tanár áll a táblánál és hirdeti az igét, s esélye sincs közel menni akár a második sorban ülő hallgatóhoz. A terem Ualakú elrendezése sokkal barátságosabb, mindenki lát mindenkit, az oktató a hallgatók közé mehet és a hallgatók között lehet. Szokatlan, de a csoportmunkát sokkal jobban támogató az olyan berendezés, ahol a padok kis csoportokban helyezkednek el, négy-hatfős csoportok tudnak egymás felé fordulva dolgozni. Sőt, még jobb, ha padok sincsenek írni praktikus, de falat emelnek - csak felhajtható asztallal rendelkező székek. A terem így bármikor könnyen átrendezhető akármilyen formába, és amennyiben írni kell, a kis asztal gyorsan előteremthető. A szemináriumi munkának amúgy sem az írás, hanem a közös munka a lényege - ezt segítse terem berendezése. Mexikóban láttunk olyan termet, ahol a hallgatók kis lehajtható asztalos, guruló székeken ültek. Ez lehetővé tette, hogy pillanatok alatt bármilyen csoportos munkára alkalmas módon rendeződjenek át.

A termekben legyen valóban korszerú multimédiás oktatástechnika, s minden teremben WIFI, hiszen óra közben is kell a hallgatóknak információt keresniük. Az oktatást segítse valamilyen elektronikus oktatástámogatási rendszer, pl. Moodle, s a Neptun vagy más tanulmányi adminisztrációs szoftver teljes funkcióskálája álljon rendelkezésre a képzés nyelvén, legyenek közösségi terek és még sok-sok minden más.

\section{AZ IDEGEN NYELVŰ KÉPZÉS BEVEZETÉSÉNEK EREDMÉNYEI}

Tudomásul kell venni, hogy az idegen nyelvú képzés létrehozása befektetés, ráadásul olyan befektetés, ami nem azonnal hozza zsákszámra a pénzt. Vannak rövid távú eredményei, de az eredmények többsége csak később jelentkezik.

\subsection{Rövid távú eredmények}

Szinte azonnali rövid távú eredmény a szisztematikusság. Ahogy azt korábban láttuk, a felkészülésnek módszeresnek, szisztematikusnak kell lennie. Ez egy más munkamódszert követel meg, ami azonnal konvertálható más területekre. A felkészülés során minőségi javulás jön létre - pl. az oktatás módszertanában - amit az érintett kollégák gyorsan hasznosítanak a napi tanításaikban. Egymással egyébként keveset érintkező kollégák közösen dolgoznak egy célért, ami javítja az intézményi összetartást, kommunikációt, javul az intézményi morál és a munkahelyi légkör.

Az idegen nyelvű képzés megindítása lehetővé teszi külföldi oktatók meghívását, megjelennek cserehallgatók, vagy ha voltak korábban, a számuk nő. Egyre több oktató tart fenn rendszeres munkakapcsolatot külföldi kollégával, egyre többen és többet utaznak külföldre és szereznek nemzetközi tapasztalatot.

\subsection{Hosszú távú eredmények}

Később az eredmények kezdenek beérni. Nagyobb számú külföldi hallgató tanul az intézményben, a számuk az összhallgatói létszámban jelentőssé válik, köztük egyre több a fizetős és nem cserehallgató. Az intézmény szerves része lesz a nemzetközi felsőoktatási térnek, integrálódik oktatásban, kutatásban és mindenféle kapcsolódó tevékenységben (pl. konferenciák, hallgatói intenzív programok). A nemzetközi képzésben tanultak átgyưrúznek az intézmény egészébe, ezáltal egy általános minőségjavulás következik be. Megváltoznak a szervezeti értékek, erősen javul a munkahely atmoszférája. Az intézmény nemzetközi akkreditációt is elnyerhet, ami a presztízsét és a hallgatóvonzó képességét növeli.

És mindezek mellett, úgy mellesleg kialakul egy stabil bevételi forrás. 


\section{KÖVETKEZTETÉSEK ÉS ZÁRÓ-GONDOLATOK}

Ezek a fenti érvek fontos érvek, fontos eredmények, fontos értékek, s érdemes is értük küzdeni. Azonban - ha reálisan gondolkodunk és őszintén beszélünk - nem ezek a legfontosabbak. Hogy mire gondolunk? Gondoljuk végig a következőket!

1. Az elmúlt évek tendenciái világosan megmutatták, hogy a magyar felsőoktatás kapacitásai lényegesen nagyobbak a jelenlegi igényeknél. A demográfiai trendek ismeretében állíthatjuk, hogy ez az arány a jövőben romlani fog: az eszkimók száma nem változik, de sokkal kevesebb lesz a fóka.

2. Az elmúlt évek azt is világosan megmutatták, hogy a felsőoktatásba jelentkezők többsége Budapesten szeretne tanulni. Ha mégsem, akkor a nagy egyetemi centrumok valamelyikében. A kis vidéki főiskolák keresettsége csökken.

3. Az állam finanszírozási hajlandósága csökken, az önálló bevételek szerepe ezért nő. Az üzleti képzésben tanuló hallgatók nagyobbik része saját maga kénytelen finanszírozni a tanulmányait.

4. A felsőoktatásba való belépés feltételei évről évre szigorodnak - nőnek a minimum pontszámok, és a nyelvvizsga belépési feltétel lesz.

5. A kis vidéki főiskolák tipikus beiskolázási köre így egyre szúkül. A hagyományos jelentkezők létszáma demográfiai okok miatt fogy, kevésbé jó képességúek, így egyre kevésbé képesek teljesíteni a belépési feltételeket, és a magasabb költségeket sem tudják megfizetni. A hagyományos beiskolázási kör nem képes fenntartani és finanszírozni ezeknek az intézményeknek a múködését, így biztosítani fennmaradásukat.

6. Tehát: új piac után kell nézniük.

A kis vidéki főiskolák nehezen képesek új piaci szegmensbe belépni. A BA szakok bővítését az állam nem támogatja, mesterképzési szándékaikat sem, és ahhoz többnyire amúgy sem rendelkeznek megfelelő emberi erőforrásokkal. Különféle OKJ-s tanfolyamok indításához a főiskolának magas a költségszintje, és - a felsőoktatási szakképzéssel együtt - lefelé pozícionálja az intézményt.

Az intézménynek nyitnia kell új piacok felé. Át kell „kódolnia” a gondolkodásmódját, és mint minden olyan gazdálkodó szervezet esetében, amelynek hazai piacai szúkülnek, külső piacokra kell lépnie. A magyar piac nagyon kicsi és szúkülő, nem lehet belőle megélni. Egy felsőoktatási intézmény ma Magyarországon csak akkor tud hosszabb távon fennmaradni, ha - mint a sikeres vállalatok döntő többsége integrálódik saját szektora nemzetközi rendszerébe, és beiskolázási körét a határon túlra is kiterjeszti.

Amennyiben erre képessé válik, az annak a jele, hogy a nemzetközi versenyben is megállja a helyét, képes ellensúlyozni a hazai piaci szúkülését, és - kapacitásai erejéig - növelni tudja hallgatóinak létszámát. Ezzel stabilitása nő, az állami forrásoktól való erős függése csökken, s képes biztosítani fennmaradását. $A z$ ilyen stabil, a nemzetközi közösségbe beágyazódott intézmény támasza környezete vállalatainak a nemzetközi piaci sikerük irányába, az ilyen intézmény környezete gyermekeit nemzetközi szinten eladható szaktudással vértezi fel, dolgozóinak pedig szakmai sikereket és biztos megélhetést képes biztosítani.

Kérdés, hogy egy intézmény meg tudja-e tenni az első nagy lépést ebbe az irányba, s sikerrel véghez tudja-e vinni? Ez - főképp egy kis vidéki főiskola számára - nem könnyű feladat. Ilyen esetben egy nagyobb, nemzetközi szinten tapasztaltabb másik intézmény segítsége, partnersége is nagyon sokat segíthet. 